Postprint of: Denton, W. \& Coysh, S.J. (2011), “Usability testing of VuFind at an academic library", Library Hi Tech, vol. 29, no. 2.

\title{
Usability Testing of VuFind at an Academic Library
}

Authors:

William Denton < wdenton@yorku.ca>

Web Librarian, York University Libraries

S237V SSB, 4700 Keele St., Toronto ON, M3J 1P3, Canada

Sarah J. Coysh <scoysh@yorku.ca>

E-Learning Librarian, York University Libraries

Frost Library, Glendon Campus, York University, 2275 Bayview Avenue,

Toronto ON, M4N 3M6, Canada

\section{Abstract}

Purpose The purpose of this paper is to present the findings of an academic library's implementation of a discovery layer (VuFind $1.0 \mathrm{RC} 1$ ) as a next-generation catalogue, based on usability testing and an online survey.

Design/ methodology/ approach We performed usability tests on ten students (eight undergraduates, two graduates), asking a set of fourteen task-oriented questions about our customized VuFind interface. Task completion was scored using a simple formula to generate a percentage indicating success or failure. Changes to the interface were made based on resulting scores and on feedback and observations of users during testing. We also ran an online survey for three weeks, to which seventy-five people responded. The results were analyzed, compared and crosstested with the findings of the usability testing.

Findings Both the usability testing and survey demonstrated that users preferred VuFind's interface over the classic catalogue. They particularly liked the facets and the richness of the search results listings. Users intuitively understood how to use the deconcatenated Library of Congress Subject Headings. Despite the discovery layer's new functionality, known journal title searching still presents a challenge to users and certain terms used in the interface were problematic.

Practical implications It is hoped that our findings will assist implementers of VuFind and other next-generation catalogues to improve their own systems. The questions add to the body of knowledge about usability testing of library catalogues.

Originality/ value There are no previous papers published documenting VuFind usability testing. Findings will be relevant, not just to VuFind, but will also add to the growing body of literature on next-generation catalogues.

Keywords Usability testing, VuFind, Discovery layer, Next-generation catalogue

Paper type Research paper 


\section{Introduction}

In 2009, York University Libraries (in Toronto, Canada) decided to implement a discovery layer to replace a confusing system that required users to search two separate databases to access the complete library holdings. One part of this system was what would become "the classic catalogue: " the obsolete WebCat online public access catalogue (OPAC), which ran in front of our integrated library system (ILS), SirsiDynix Unicorn 3.2. Almost everything in our collections, physical or online, is in this system. The other part was our locally-developed electronic resource management system (ERM). All online resources are indexed in that system, but there are some eResources in the ERM that are not in the SirsiDynix catalogue, such as electronic journals and books in aggregator databases.

Users who wanted to be certain of our complete holdings had to search both systems. Our home page had a "Title Quick Search" text input box with two radio buttons: Catalogue and eResources (see Figure 1). The catalogue option did a leftanchored title search of our SirsiDynix catalogue and the eResources option searched our ERM. We had a large amount of anecdotal data and personal experience about the inadequacies of this system, including results from our 2007 LibQUAL+ survey on library service quality that showed the categories "a library Web site enabling me to locate information on my own," "the electronic information resources I need," and "easy-to-use access tools that allow me to find things on my own" were all perceived as being "less than desired" (York University Libraries 2007).

Find by title: books, journals, databases, more

OCatalogue $\odot$ eResources

Figure 1: The old "Title Quick Search" box, reflecting two silos, the OPAC and the ERM

To address these problems, we decided to implement a discovery layer. We had seven key criteria for the system. It had to:

1. allow us to make searchable everything in all our systems;

2. be intuitive to use;

3. have a flexible user interface;

4. be in use at other academic libraries;

5. provide real-time availability;

6. support enriched content such as book covers and comments; and

7. support non-Roman scripts.

University libraries in Ontario work closely together and we knew that others at the time had implemented or were planning to deploy Primo, Endeca, Evergreen (possibly with a discovery layer on top), and BiblioCommons. Because we collaborate on Scholars Portal, an Ontario academic consortium that owns over 20,000,000 articles, we wanted a flexible system that would integrate standards-based services and metadata that Scholars Portal or other universities might provide. We investigated Primo, AquaBrowser, Endeca, and VuFind. (For a current overview and comparison of these and other discovery tools, both open source and commercial, see Yang and Wagner (2010)). Ultimately we chose VuFind, primarily because it was free, both in price and by software license. 
Before releasing the new catalogue to the public, we wanted to test its usability and make any necessary interface changes based on those findings. This paper describes the in-person usability testing we did with ten students, as well as the results of an online survey open to all users of the new catalogue. Based on these findings, we updated the interface to address identified problems and improve usability.

\section{About VuFind}

VuFind is a next-generation catalogue that harvests data from OPACs and other sources, such as digital repositories, creating a single searchable index (Sadeh, 2008). This decoupled architecture "provides the capability to create a better user experience for a given collection but also unifies the discovery processes across heterogeneous collections" (Sadeh, p. 11). Fagan (2010) explains that discovery layers like VuFind "seek to provide an improved experience for library patrons by offering a more modern look and feel, new features, and the potential to retrieve results from other major library systems such as article databases" (p. 58).

According to Antelman et al. (2006), the three main improvements that a discovery layer provides are relevance-ranked results, new browsing capabilities, and improved subject access.

VuFind is written in PHP and uses the search engine Solr to index MARC records. It was created by Andrew Nagy at Villanova University in 2007 to work with their Voyager system, and has since grown into a world-wide software project that can be placed in front of many different ILSes. As of November 2010 some of the libraries testing and/or using VuFind include the National Library of Australia, Stanford, Yale and Georgia Tech (Falvey Memorial Library, Villanova University).

VuFind offers a single-box search, like Google and other search engines. Its relevancy rankings are adjustable so that each institution can customize the ordering of search results. Unlike many ILSes, it can search any MARC field it is configured to recognize. Spelling mistakes are noted and there is a "did you mean" suggestion feature. Although VuFind is not part of the ILS, live availability status of items is possible through Ajax calls that are made when an item's web page loads. The interface is also available in multiple languages.

VuFind deconcatenates Library of Congress Subject Headings, making each element of a subject heading a hyperlink to a search: the further to the left, the broader the search; the further to the right, the narrower. For example, the book Critical Observations (see usability question 7.1, below) has one heading: "Literature, Modern--20th Century--History and criticism." In our old catalogue, this entire string was one link, leading to other items with that exact heading. In VuFind, the three elements are separated and it is possible to follow "Literature, Modern," "20th Century," or "History and criticism" as a link. The "Literature, Modern" link leads to a search for all items with that subject. The "20th Century" link leads to a search for all items with the subject "Literature, Modern--20th Century." "History and criticism" leads to a search for all items with the full "Literature, Modern--20th Century--History and criticism" subject.

Before testing the deconcatenated subject headings we changed the hyphens to guillemets ("»") to indicate a hierarchy or breadcrumb trail. Next we implemented special underlining and tooltips when the user hovered the pointer over the subject 
links. Everything from the beginning of the subject string up to what the pointer hovered over would be underlined, to show that was the string that would be searched (see Figure 2).

Main Author: Symons, Julian, 1912-

Format: 同 Book

Language: English

Published: New Haven : Ticknor \& Fields 1981

Subjects: Literature, Modern $»$ 20th century $»$ History and criticism.

Physical Description: 213 p. ; $22 \mathrm{~cm}$.

Literature, Modern $» 20$ th century

Item Description: "A Joan Kahn book."

Figure 2: Tooltips on deconcatenated LCSH

VuFind sorts and displays search results on criteria such as format, location, subject, author, language, and call number. These facets allow users to narrow large sets of search results to smaller more defined sets. Another feature of VuFind is the "similar items" list. At the individual record level, similar items are displayed based on the item title. VuFind allows tagging, commenting, keeping a list of favourites, and sending search results as text messages or email. However, Ho et al. (2008) observed in their study at Western Michigan University-matched anecdotally by Yale, Michigan, and other institutions-that students were not using the tagging feature and very few used the comments, favorites and texting.

Figure 3 shows a screenshot of our VuFind catalogue as it is at time of writing (November 2010). The top facets are visible on the left; below Format are Subject, Author, Call Number, and Language. The search results are on the right. 


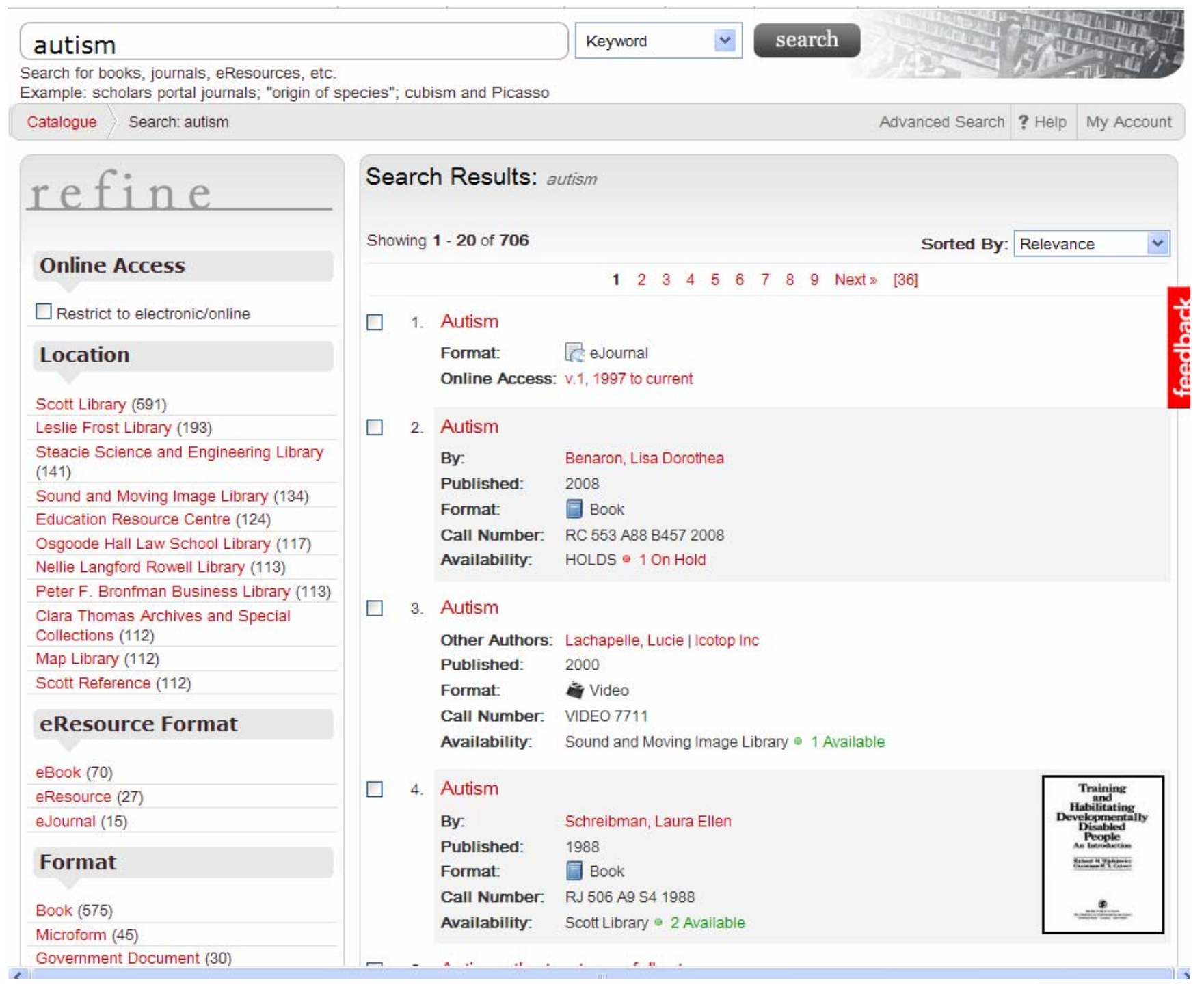

Figure 3: Screenshot of VuFind catalogue in November 2010, showing facets on left and search results on right.

\section{Literature review of discovery layer usability testing}

Large and Beheshti (1997) summarized the large body of literature on OPACs published before 1997, and we refer the reader to its excellent discussion for a historical overview. Antelman et al. (2006) identify three previous generations of online catalogues. The first, in the 1960 s and 1970s, was primarily an online way of accessing the card catalogue with the same entry points as a printed catalogue, and was based on the expectation that most users were interested in known-item searching. The second provided keyword and post-coordinate Boolean searching, though Boolean was still a retrieval technique designed for experienced searchers and was difficult for the untrained user. The third generation was the (at the time) "next-generation" catalogue that emerged in the early 1980s. These experimental systems, like Okapi and Cheshire II, "incorporated advanced search and matching techniques developed by researchers in information retrieval ... they typically did not 
rely on exact match (Boolean) but used partial-match techniques (probabilistic and vector-based)" (p. 128). Despite these experimental catalogues, "all major ILS vendors are still marketing catalogs that represent second-generation functionality" (p. 129).

Antelman et al. observe that "library catalogs have represented stagnant technology for close to twenty years" and as a result the catalogue has become "a call-number lookup system, with resource discovery happening elsewhere" (2006, p. 128). Sadeh (2008) identifies two problems with current library systems: first, they "are inherently librarian-centric; their design in terms of data structures and workflows is focused on library administration and hence severely limits the possibilities for the end-user interface" (p. 10). Second, "existing library collections are fragmented, offered by multiple library systems, each of which focuses on specific types of materials-physical items, locally digitized materials, remote ejournal collections, or others" (p. 10). For this reason libraries have not been able to provide a unified entry point to their collections. As Ho et al. outline, some libraries are dealing with the outdated catalogue interfaces by selecting new ILSes and others are investigating open source catalogue systems and frameworks such as Evergreen and the extensible Catalog (2008).

To improve their outdated interface, North Carolina State University (NCSU) was the first academic library to implement a discovery layer based on a decoupled architecture. They used Endeca, a commercial search engine that allowed faceted browsing of results. In other research, NCSU conducted usability testing to compare student success in the new and old catalogue interfaces (Antelman et al. 2006). Ten undergraduates were tested, five on each interface. The test contained four knownitem tasks and six topical-searching tasks. The researchers observed a significant decrease of average task duration for Endeca users, an increased percentage of tasks that were completed easily in Endeca, and the nearly equivalent decrease in the percentage of tasks that were rated as hard to complete. Participants using both the new and old interfaces expressed confusion over some of the terminology. One of the most problematic terms was "subject," as participants did not recognize that this term referred to controlled vocabulary assigned to records. Participants identified that relevance ranking of results was the most important improvement to the new catalogue.

Olson (2007) describes a study of AquaBrowser, a discovery layer now owned by SerialsSolutions, to investigate the effect of faceted browsing on the scholarly research of users. Twelve PhD students in the humanities and social sciences were the subjects. The findings indicated that the discovery layer assisted students in finding new materials through the facets and a word cloud feature. Most participants understood that facets were a refinement tool, and the comments were overwhelmingly positive. Olson also found that subjects had a clear idea of which facets would or would not be useful to them. This seemed to vary among the subjects, however: several cited the format facet, particularly "videos," "music," or "microfilm" as time-savers (p. 556). Only two participants felt the interface was not an improvement over the original catalogue, some participants wanted to limit to multiple languages or dates, and a few were confused by the same term appearing in multiple facets, e.g. "music" as a format and a topic. Olson suggested that "if faceted navigation can better match consumers to the goods that they specifically are interested [in], perhaps libraries can expect similar results in matching scholars to the research materials that best fit their specific needs" ( $p .551$ ). 
Sadeh (2008) describes two usability studies of Primo, a discovery layer owned by ExLibris, conducted by the University of Minnesota in 2006 and 2007. There were eight participants in each, with seven scenarios in the first study and nine in the second. Participants felt the interface was "friendly, easy to use, and easy to learn" (p. 22) and were able to complete the assigned tasks with minimal help and without any prior knowledge of the system. All participants also reported that faceted browsing was useful as a means of narrowing down the result lists, and considered the facets to be one of the differentiating features between the discovery layer and their library OPAC. Participants were positive about the tagging capabilities and the options to view only items available online or currently in the library. Participants described the interface as "clear," "no distractions," "straightforward," "informative," and "efficient" (p. 23). Testers identfied a few minor issues, related mainly to terminology, icon design, the need for additional links and system feedback, and the manner in which the services were displayed.

There are no formally published studies examining the usability of VuFind, though the Usability and Assessment Department of Yale University Library performed two tests in 2008. The first, "Usability Test of VuFind as a Subject-Based Display of Ebooks," examined a medical library's very focused implementation of VuFind to present lists of ebooks in predetermined subjects (Bauer, 2008a). The reaction of the study participants, primarily medical and nursing students, was mixed, as most preferred to search, and found browsing a list less efficient. Interestingly, the search for known items was reported to work well for participants, while searching for broad topics seemed to produce less valuable results. Bauer noted "participants expected medical books only, and the inclusion of a wide array of material from other disciplines was sometimes disconcerting" (p. 1). She also found that the facets worked well for some participants although they did comment that they did not think they were always noticeable.

The second study, "Yale University Library VuFind Test-Undergraduates," was performed with five undergraduates. It outlined areas where improvements with VuFind (version 0.8 ) could be made including "the need for a more robust spell checking, a more precise search algorithm with better relevancy ranking, and better topic facets" (Bauer 2008b). It also found that the least desired feature was tagging and that related items features needed to be better configured or mimic the physical action of browsing a shelf in the library.

Western Michigan Libraries performed a usability test using the questions from Bauer (2008b), but they also have not published their findings. They found that the vast majority of users were not interested in "the Web 2.0 bells and whistles" (Ho et al. 2009, p. 90) and they feel that this is due to the catalogue being a searching tool and not a social network tool.

\section{Methodology}

In the summer of 2010 we set up a test instance of VuFind $1.0 \mathrm{RC} 1$ and loaded data from our SirsiDynix catalogue, our ERM, and our instances of DSpace and Open J ournal Systems. We made numerous changes to the look and feel to make VuFind fit our university web template, and we removed features such as the citation generator, which was not always correct, and links to author entries in Wikipedia. 
We examined VuFind's usability through both in-person testing and an online survey. Research by Nielsen and Landauer (1993) and Nielsen (2000) shows that testing five users will find $85 \%$ of usability problems, and Nielsen (2000) recommends doing multiple rounds of testing with five users rather than one round with a larger number of users. Because we only had time for one round of testing, we decided to use ten test volunteers to catch as many problems as possible.

To find student subjects we placed an announcement on our home page and posted flyers. We explained that the test would take about an hour, and offered a $\$ 20$ bookstore gift certificate as compensation. More than ten people volunteered, and we selected from this group in order to have a representative sample of students from different disciplines and in various years of study. We had two first-year students, one second-year, three third-years, two fourth-years, and two midway through their PhDs. The undergraduates were studying business, chemistry, English, geography, kinesiology, psychology and sociology, and the PhD students were in education and linguistics.

The usability questions were based on those used by Antelman et al. (2006) and Bauer (2008b), and were adapted to suit our local needs, including an examination of Web 2.0 functionality. In each 45-minute session we wanted to record all of the subject's words and actions. To capture their thoughts, we had one test administrator write down everything they said. We used the think-aloud protocol, and explained, "To make sure that we capture everything about how you use the site, we need you to talk out loud. More importantly, let us know when you're stuck or something does not make sense. Please keep in mind that we are testing the library catalogue and not you! If you find that something does not make sense or the answer is not obvious, this is the information we need to make changes." To capture what they did, another test administrator recorded their actions, and as a backup we did a full-motion screen capture with Adobe Captivate. A third test administrator asked the questions.

Users began at a test instance of our redesigned home page that had a search box prominently displayed in the centre of the page (see Figure 4). It linked to our test instance of VuFind. Task success was measured based on the user success rate formula outlined by Nielsen (2001), with partial success meaning there was some degree of failure or the student required slight prompting:

success $\%=100 *$ (number_fully_successful $+0.5 *$ number_partially_successful) / number_of_participants

Along with the usability testing we also administered a voluntary online survey that ran for three weeks in November 2009. A short invitation to take the survey was shown to users on the first search results screen which users saw after going into the VuFind beta from the library home page. We based the questions on Bauer (2008c). Seventy-five people responded. 


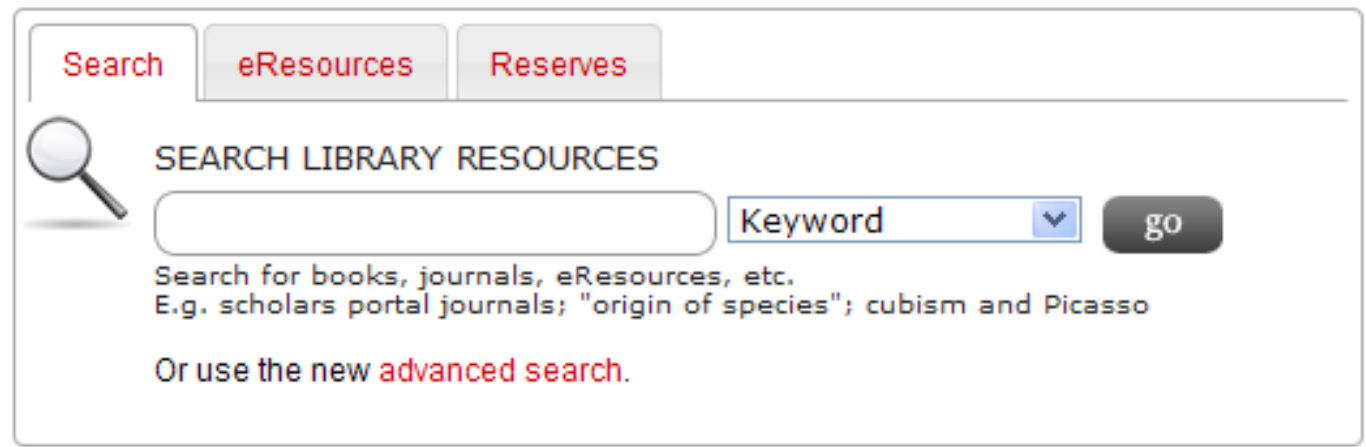

Figure 4: The new VuFind search box on the home page

\section{Usability testing and online survey results}

The usability questions and findings are summarized in Table 1, and the online survey in Table 2. A general discussion follows.

Table 1: Summary of usability findings.

\begin{tabular}{|c|c|c|c|c|}
\hline & Question & Findings & Success & Comments/ Actions \\
\hline & $\begin{array}{l}\text { I ntroductory } \\
\text { questions }\end{array}$ & & & \\
\hline 1.1 & $\begin{array}{l}\text { What is your } \\
\text { expectation of what you } \\
\text { will find in the library } \\
\text { catalogue? }\end{array}$ & $\begin{array}{l}\text { Books ( } 7) \text {, journals } \\
\text { and ejournals ( } 5), \\
\text { also mentioned } \\
\text { databases, videos, } \\
\text { etc. }\end{array}$ & $\mathrm{n} / \mathrm{a}$ & $n / a$ \\
\hline 1.2 & $\begin{array}{l}\text { How often do you use } \\
\text { the library catalogue? }\end{array}$ & $\begin{array}{l}\text { Every day (1), } \\
\text { multiple times a } \\
\text { week (4), once a } \\
\text { week (2), } \\
\text { "sometimes, not a } \\
\text { lot" (2), once a } \\
\text { month (1). }\end{array}$ & $\mathrm{n} / \mathrm{a}$ & $n / a$ \\
\hline 1.3 & $\begin{array}{l}\text { What do you use it for } \\
\text { most often? }\end{array}$ & $\begin{array}{l}\text { To find books ( } 7) \text {, } \\
\text { journals ( } 5) \text {, } \\
\text { information of any } \\
\text { kind on a specific } \\
\text { topic (3). }\end{array}$ & $\mathrm{n} / \mathrm{a}$ & $n / a$ \\
\hline \multirow[t]{2}{*}{1.4} & $\begin{array}{l}\text { How do you generally } \\
\text { search it? }\end{array}$ & Title (7), Author (3). & $\mathrm{n} / \mathrm{a}$ & $\begin{array}{l}\text { Reflected limitations } \\
\text { of WebCat system. } \\
\text { Make Title and } \\
\text { Author second and } \\
\text { third in parameter } \\
\text { list (after Keyword). }\end{array}$ \\
\hline & Finding a book & & & \\
\hline
\end{tabular}




\begin{tabular}{|c|c|c|c|c|}
\hline 2.1 & $\begin{array}{l}\text { You're taking a course } \\
\text { on the plays of William } \\
\text { Shakespeare and your } \\
\text { professor has requested } \\
\text { that you read Othello. } \\
\text { Can you find an } \\
\text { available copy? }\end{array}$ & $\begin{array}{l}\text { Eight people used } \\
\text { Title Keyword for } \\
\text { "Othello," two used } \\
\text { Keyword. Two first } \\
\text { made their way to } \\
\text { advanced search, } \\
\text { ignoring basic search } \\
\text { on home page. }\end{array}$ & $100 \%$ & None. \\
\hline 2.2 & $\begin{array}{l}\text { What do you think of } \\
\text { the format of the search } \\
\text { results? }\end{array}$ & $\begin{array}{l}\text { Four people noticed } \\
\text { the facet refinements } \\
\text { on the left-hand side. } \\
\text { Four liked the } \\
\text { amount of } \\
\text { information shown in } \\
\text { the results list, so } \\
\text { they did not need to } \\
\text { go to a record view. }\end{array}$ & $n / a$ & None. \\
\hline \multirow[t]{2}{*}{2.3} & $\begin{array}{l}\text { [Have them load a } \\
\text { record view page] What } \\
\text { do you see on this } \\
\text { page, and what do you } \\
\text { think about it? }\end{array}$ & $\begin{array}{l}\text { Six had favourable } \\
\text { comments; six noted } \\
\text { easy visibility of item } \\
\text { availability. Three } \\
\text { wanted cover images } \\
\text { for all items. }\end{array}$ & $n / a$ & $\begin{array}{l}\text { Add item availability } \\
\text { to the search results } \\
\text { page. }\end{array}$ \\
\hline & $\begin{array}{l}\text { Finding materials in a } \\
\text { specific branch, and } \\
\text { intercampus } \\
\text { borrowing }\end{array}$ & & & \\
\hline 3.1 & $\begin{array}{l}\text { Can you find an } \\
\text { available copy of any } \\
\text { edition of Othello at the } \\
\text { Frost Library? }\end{array}$ & $\begin{array}{l}\text { Five used Location } \\
\text { facet, three scanned } \\
\text { results until they saw } \\
\text { the right location, } \\
\text { two did an advanced } \\
\text { search with location } \\
\text { limited. }\end{array}$ & $95 \%$ & $\begin{array}{l}\text { Illustrates variety of } \\
\text { approaches users } \\
\text { can take to one task. } \\
\text { No changes. }\end{array}$ \\
\hline \multirow[t]{2}{*}{3.2} & $\begin{array}{l}\text { How would you get this } \\
\text { book from the Frost } \\
\text { library? }\end{array}$ & $\begin{array}{l}\text { Six noticed } \\
\text { intercampus } \\
\text { borrowing option, } \\
\text { two said they would } \\
\text { just go there but saw } \\
\text { option when } \\
\text { prompted. }\end{array}$ & $80 \%$ & $\begin{array}{l}\text { Ask more targeted } \\
\text { question next time. } \\
\text { No changes. }\end{array}$ \\
\hline & $\begin{array}{l}\text { Finding a movie } \\
\text { version }\end{array}$ & & & \\
\hline 4 & $\begin{array}{l}\text { Is there a movie version } \\
\text { of the play Othello } \\
\text { currently available for } \\
\text { borrowing? }\end{array}$ & $\begin{array}{l}\text { Eight fully successful, } \\
\text { two partially. Six } \\
\text { used facets to refine } \\
\text { location, three used } \\
\text { facets to refine }\end{array}$ & $90 \%$ & $\begin{array}{l}\text { Next time ask them } \\
\text { to find a different } \\
\text { DVD that would not } \\
\text { be on the list of } \\
\text { results being viewed. }\end{array}$ \\
\hline
\end{tabular}




\begin{tabular}{|c|c|c|c|c|}
\hline & & format. & & No changes. \\
\hline & $\begin{array}{l}\text { Finding items by a } \\
\text { known author }\end{array}$ & & & \\
\hline \multirow[t]{2}{*}{5} & $\begin{array}{l}\text { You read an article that } \\
\text { refers to a financial } \\
\text { economist named } \\
\text { Stephen Ross, and } \\
\text { you'd like to know if the } \\
\text { library has any of his } \\
\text { books. What is the title } \\
\text { of one of his books? }\end{array}$ & $\begin{array}{l}\text { Everyone used } \\
\text { Author Keyword with } \\
\text { "Stephen Ross", then } \\
\text { scanned results for } \\
\text { something about } \\
\text { finance. Two people } \\
\text { had to repeat the } \\
\text { search. }\end{array}$ & $90 \%$ & None. \\
\hline & Using Favourites & & & \\
\hline 6.1 & $\begin{array}{l}\text { Let's say that this book } \\
\text { looks interesting to you } \\
\text { and you might want to } \\
\text { use it later, how would } \\
\text { you keep a record of it } \\
\text { for future reference? }\end{array}$ & $\begin{array}{l}\text { Six successful, two } \\
\text { partial. Confusion } \\
\text { over Favourites in } \\
\text { VuFind and } \\
\text { Favourites (as } \\
\text { bookmarks) in } \\
\text { Internet Explorer. }\end{array}$ & $70 \%$ & $\begin{array}{l}\text { Rename Favourites } \\
\text { to My List. }\end{array}$ \\
\hline \multirow[t]{2}{*}{6.2} & $\begin{array}{l}\text { Please show me how } \\
\text { you'd save this book in } \\
\text { this system. }\end{array}$ & $\begin{array}{l}\text { Nine successful, but } \\
\text { numerous } \\
\text { usability/interface } \\
\text { problems found. }\end{array}$ & $90 \%$ & $\begin{array}{l}\text { I mprove interface, } \\
\text { show existing } \\
\text { metadata when } \\
\text { adding items to My } \\
\text { List; better indication } \\
\text { of success. }\end{array}$ \\
\hline & $\begin{array}{l}\text { Known item } \\
\text { searching }\end{array}$ & & & \\
\hline 7.1 & $\begin{array}{l}\text { Please find the book } \\
\text { Critical Observations by } \\
\text { Julian Symons. }\end{array}$ & $\begin{array}{l}\text { Five used Title } \\
\text { Keyword, two Author } \\
\text { Keyword, two } \\
\text { general keyword. }\end{array}$ & $100 \%$ & None. \\
\hline \multirow[t]{2}{*}{7.2} & $\begin{array}{l}\text { How would you find } \\
\text { more on the subject of } \\
\text { modern literature of the } \\
\text { twentieth century, } \\
\text { specifically history and } \\
\text { criticism? }\end{array}$ & $\begin{array}{l}\text { Nine clearly } \\
\text { understood } \\
\text { deconcatenated LCSH } \\
\text { subjects with } \\
\text { underline cues (see } \\
\text { discussion below). }\end{array}$ & $90 \%$ & None. \\
\hline & $\begin{array}{l}\text { Subject searching } \\
\text { and more }\end{array}$ & & & \\
\hline 8.1 & $\begin{array}{l}\text { How would you find } \\
\text { resources on cell } \\
\text { biology? }\end{array}$ & $\begin{array}{l}\text { When search terms } \\
\text { don't match LCSH, } \\
\text { the user does not } \\
\text { realize that they are } \\
\text { not seeing all the } \\
\text { holdings on that } \\
\text { subject (see } \\
\text { discussion below). }\end{array}$ & $20 \%$ & $\begin{array}{l}\text { Change menu option } \\
\text { to "Subject Keyword" } \\
\text { and add examples to } \\
\text { highlight that it's } \\
\text { LCSH and not natural } \\
\text { language. }\end{array}$ \\
\hline
\end{tabular}




\begin{tabular}{|c|c|c|c|c|}
\hline 8.2 & $\begin{array}{l}\text { Can you find the most } \\
\text { recently published } \\
\text { materials on this } \\
\text { subject? }\end{array}$ & $\begin{array}{l}\text { Resorting from } \\
\text { relevancy to date } \\
\text { was successful for } \\
\text { seven, partial for } \\
\text { three. }\end{array}$ & $85 \%$ & None. \\
\hline 8.3 & $\begin{array}{l}\text { With a general search } \\
\text { like this, how would you } \\
\text { pick an item from the } \\
\text { list, especially if you } \\
\text { didn't automatically } \\
\text { recognize the titles? } \\
\text { What information is } \\
\text { important to you in } \\
\text { making the choice? }\end{array}$ & $\begin{array}{l}\text { Four said currency, } \\
\text { four said they would } \\
\text { narrow by topic } \\
\text { facet, three said title, } \\
\text { two said subject } \\
\text { headings. }\end{array}$ & $n / a$ & $\begin{array}{l}\text { Currency and title } \\
\text { keywords are } \\
\text { important, and } \\
\text { narrowing by facets. }\end{array}$ \\
\hline 8.4 & $\begin{array}{l}\text { Please look under } \\
\text { Format on the left-hand } \\
\text { side. What would you } \\
\text { expect to find if you } \\
\text { clicked on Electronic? }\end{array}$ & $\begin{array}{l}\text { Two mentioned three } \\
\text { or more kinds of } \\
\text { eResources such as } \\
\text { articles, PDFs, } \\
\text { ebooks, CDs, DVDs, } \\
\text { audio. Eight } \\
\text { mentioned only one } \\
\text { or two formats. }\end{array}$ & $n / a$ & $\begin{array}{l}\text { Change to our } \\
\text { standard term for } \\
\text { online resources: } \\
\text { eResources. }\end{array}$ \\
\hline 8.5 & $\begin{array}{l}\text { [Make them click on it.] } \\
\text { Is that what you } \\
\text { expected? }\end{array}$ & $\begin{array}{l}\text { Five said no, two said } \\
\text { yes. Three were } \\
\text { unclear. }\end{array}$ & $\mathrm{n} / \mathrm{a}$ & $\begin{array}{l}\text { Using term } \\
\text { "eResources" will } \\
\text { align results with } \\
\text { expectations. }\end{array}$ \\
\hline 8.6 & $\begin{array}{l}\text { If you clicked on the } \\
\text { limiter for a specific } \\
\text { library such as the } \\
\text { Steacie Science Library, } \\
\text { would you still expect to } \\
\text { see all of the electronic } \\
\text { resources listed? }\end{array}$ & $\begin{array}{l}\text { Four said yes, five } \\
\text { said no. }\end{array}$ & $\mathrm{n} / \mathrm{a}$ & $\begin{array}{l}\text { We show electronic } \\
\text { resources after } \\
\text { narrowing to a } \\
\text { branch. }\end{array}$ \\
\hline \multirow[t]{2}{*}{8.7} & $\begin{array}{l}\text { If you wanted to return } \\
\text { to the list of everything } \\
\text { that's available, how } \\
\text { would you do that? }\end{array}$ & $\begin{array}{l}\text { Users preferred the } \\
\text { back button; three } \\
\text { noticed the list of } \\
\text { limiters resulting } \\
\text { from their searching } \\
\text { and recognized the } \\
\text { purpose of limiter- } \\
\text { removing minus sign } \\
\text { icon; four more did } \\
\text { after prompting. }\end{array}$ & $50 \%$ & $\begin{array}{l}\text { Change icon to } \\
\text { standard small } X \text {. }\end{array}$ \\
\hline & Boolean OR & & & \\
\hline 9 & $\begin{array}{l}\text { How would you search } \\
\text { for resources on } \\
\text { corporate finance or } \\
\text { accounting? }\end{array}$ & $\begin{array}{l}\text { One successful, four } \\
\text { partial. Users } \\
\text { expected Boolean } \\
\text { operators to work in }\end{array}$ & $30 \%$ & $\begin{array}{l}\text { Make Boolean } \\
\text { operators work in } \\
\text { lower case. }\end{array}$ \\
\hline
\end{tabular}




\begin{tabular}{|c|c|c|c|c|}
\hline & & $\begin{array}{l}\text { lower case, as in the } \\
\text { classic catalogue and } \\
\text { databases. }\end{array}$ & & \\
\hline & $\begin{array}{l}\text { Finding a known } \\
\text { journal issue }\end{array}$ & & & \\
\hline \multirow[t]{2}{*}{10} & $\begin{array}{l}\text { You have the citation } \\
\text { for a journal article. } \\
\text { Using the library } \\
\text { catalogue, can you find } \\
\text { if the library has this } \\
\text { particular issue of this } \\
\text { journal? }\end{array}$ & $\begin{array}{l}\text { Four partially } \\
\text { successful. Display of } \\
\text { holdings information } \\
\text { was very unhelpful, } \\
\text { and users wanted a } \\
\text { way to search by } \\
\text { periodical title. }\end{array}$ & $20 \%$ & $\begin{array}{l}\text { Show clear and } \\
\text { complete holdings } \\
\text { information; add } \\
\text { periodical title } \\
\text { search. }\end{array}$ \\
\hline & Facets & & & \\
\hline 11.1 & $\begin{array}{l}\text { Please look under } \\
\text { Refine on the left-hand } \\
\text { side. Which limits would } \\
\text { be the most useful for } \\
\text { your research? }\end{array}$ & $\begin{array}{l}\text { Topic (7), Location } \\
\text { (6); Format, Call } \\
\text { number (4); } \\
\text { Language (3); Author } \\
\text { (2); Region, Era (1). }\end{array}$ & $n / a$ & $\begin{array}{l}\text { Move Topic facet up, } \\
\text { beneath Location } \\
\text { and Format. }\end{array}$ \\
\hline 11.2 & $\begin{array}{l}\text { Are any of them } \\
\text { unclear? }\end{array}$ & $\begin{array}{l}\text { Era and Region were } \\
\text { generally } \\
\text { misunderstood to be } \\
\text { date and place of } \\
\text { publication; they } \\
\text { were also sparsely } \\
\text { populated. }\end{array}$ & $\mathrm{n} / \mathrm{a}$ & $\begin{array}{l}\text { Remove Era and } \\
\text { Region facets. }\end{array}$ \\
\hline 11.3 & $\begin{array}{l}\text { Which wouldn't you } \\
\text { use? }\end{array}$ & $\begin{array}{l}\text { Subjects identified } \\
\text { that they generally } \\
\text { all seemed possibly } \\
\text { useful. }\end{array}$ & $\mathrm{n} / \mathrm{a}$ & None. \\
\hline \multirow[t]{2}{*}{11.4} & Are any missing? & No. & $\mathrm{n} / \mathrm{a}$ & None. \\
\hline & Favourites again & & & \\
\hline \multirow[t]{2}{*}{12} & $\begin{array}{l}\text { Now you'd like to look } \\
\text { at that book that you } \\
\text { saved in your } \\
\text { Favourites before. Can } \\
\text { you show me how you'd } \\
\text { get back to it? }\end{array}$ & $\begin{array}{l}\text { All but one found it } \\
\text { very easy to get back } \\
\text { to the Favourites list. }\end{array}$ & $90 \%$ & $\begin{array}{l}\text { None (after } \\
\text { "Favourites" is } \\
\text { renamed "My List"). }\end{array}$ \\
\hline & Wrap-up questions & & & \\
\hline 13.1 & $\begin{array}{l}\text { What words would you } \\
\text { use to describe the tool } \\
\text { you just used? }\end{array}$ & $\begin{array}{l}\text { Six said "user } \\
\text { friendly," three } \\
\text { "easier," two "good." }\end{array}$ & $\mathrm{n} / \mathrm{a}$ & \\
\hline 13.2 & $\begin{array}{l}\text { What did you like about } \\
\text { the new catalogue } \\
\text { interface? }\end{array}$ & $\begin{array}{l}\text { Facets; that search } \\
\text { results showed all } \\
\text { the information } \\
\text { necessary so no } \\
\text { drilling down was }\end{array}$ & $\mathrm{n} / \mathrm{a}$ & \\
\hline
\end{tabular}




\begin{tabular}{|c|c|c|c|c|}
\hline & & $\begin{array}{l}\text { needed; that } \\
\text { availability used } \\
\text { green font. }\end{array}$ & & \\
\hline 13.3 & $\begin{array}{l}\text { What did you dislike } \\
\text { about the new } \\
\text { catalogue interface? }\end{array}$ & $\begin{array}{l}\text { Two mentioned } \\
\text { Region and Era } \\
\text { facets; Topic facet; } \\
\text { having to log in to } \\
\text { Favourites; graphic } \\
\text { design. }\end{array}$ & $n / a$ & \\
\hline \multirow[t]{2}{*}{13.4} & $\begin{array}{l}\text { What one feature } \\
\text { stands out for you the } \\
\text { most? }\end{array}$ & $\begin{array}{l}\text { Facet and search } \\
\text { results richness. }\end{array}$ & $\mathrm{n} / \mathrm{a}$ & \\
\hline & Books preview & & & \\
\hline 14 & $\begin{array}{l}\text { Would you like to be } \\
\text { able to see a preview of } \\
\text { a book in the library } \\
\text { catalogue before getting } \\
\text { it from the shelf? }\end{array}$ & $\begin{array}{l}\text { Showing if previews } \\
\text { are available at } \\
\text { Google Books, the } \\
\text { Open Library, or } \\
\text { similar sources would } \\
\text { be very popular. }\end{array}$ & $80 \%$ yes & $\begin{array}{l}\text { Add links to previews } \\
\text { where available, } \\
\text { using Google Books } \\
\text { API. }\end{array}$ \\
\hline
\end{tabular}

Table 2: Results of the online survey

\begin{tabular}{|c|c|c|}
\hline & Question & Results \\
\hline 1 & $\begin{array}{l}\text { How did you find out about the } \\
\text { new catalogue interface? } \\
\text { (Multiple answers permitted) }\end{array}$ & $\begin{array}{l}\text { - } \quad \text { Library home page: } 62(83 \%) \\
\text { - } \quad \text { Librarian: } 8(6 \%) \\
\text { - } \quad \text { Student portal: } 3(4 \%) \\
\text { - } \quad \text { Faculty member: } 2(3 \%) \\
\text { - } \quad \text { Other: } 4(5 \%)\end{array}$ \\
\hline 2 & $\begin{array}{l}\text { What were you looking for in the } \\
\text { catalogue today? } \\
\text { (Free text question) }\end{array}$ & $\begin{array}{l}73 \text { responded, two wanting two kinds of } \\
\text { items. } 24 \text { were looking for books; } 23 \text { were } \\
\text { looking for items by subject, course, or with } \\
\text { some other particular research need; } 21 \text { were } \\
\text { looking for articles, generally by citation; four } \\
\text { wanted videos; three said nothing. We see } \\
\text { the mix of goals people have when using a } \\
\text { catalogue, and the importance of making } \\
\text { articles easy to find, which VuFind does not } \\
\text { yet solve for us. }\end{array}$ \\
\hline 3 & $\begin{array}{l}\text { Were you able to find what you } \\
\text { were looking for using the new } \\
\text { catalogue interface? }\end{array}$ & $\begin{array}{l}\text { - Yes: } 63(84 \%) \\
\text { - No: } 12(16 \%)\end{array}$ \\
\hline 4 & $\begin{array}{l}\text { Did you find the new catalogue } \\
\text { interface easy to use? }\end{array}$ & $\begin{array}{l}\text { - Yes: } 64(85 \%) \\
\text { - No: } 5(7 \%) \\
\text { - } \text { Other (found it easy but had some }\end{array}$ \\
\hline
\end{tabular}




\begin{tabular}{|c|c|c|}
\hline & & concerns): $6(8 \%)$ \\
\hline 5 & $\begin{array}{l}\text { Did you find your search results } \\
\text { were what you expected? }\end{array}$ & $\begin{array}{l}\text { - Yes: } 68(92 \%) \\
\text { - No: } 6(8 \%)\end{array}$ \\
\hline 6 & $\begin{array}{l}\text { Did you use the "Refine" options } \\
\text { on the left-hand side? }\end{array}$ & $\begin{array}{l}\text { - Yes: } 33(45 \%) \\
\text { - No: } 41(55 \%)\end{array}$ \\
\hline 7 & $\begin{array}{l}\text { If you used them, which "Refine" } \\
\text { options did you find helpful? } \\
\text { (Multiple answers permitted; } 34 \\
\text { respondents) }\end{array}$ & $\begin{array}{ll}\text { - } & \text { Format: } 17(50 \%) \\
\text { - } & \text { Author: } 17(50 \%) \\
\text { - } & \text { Topic: } 15(44 \%) \\
\text { - } & \text { Location: } 14(41 \%) \\
\text { - } & \text { Language: } 6(18 \%) \\
\text { - } & \text { Region: } 4(11 \%) \\
\text { - } & \text { Call number: } 3(9 \%) \\
\text { - } & \text { Era: } 2(6 \%)\end{array}$ \\
\hline 8 & $\begin{array}{l}\text { Did you find any of these features } \\
\text { useful? (Multiple answers } \\
\text { permitted; } 61 \text { respondents) }\end{array}$ & 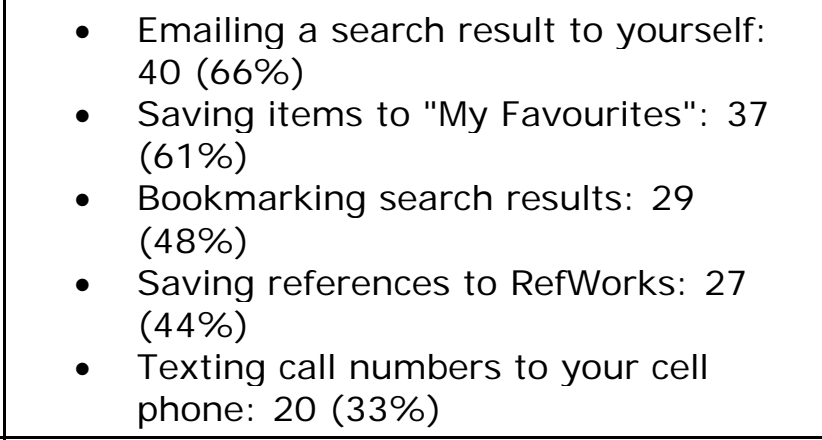 \\
\hline 9 & $\begin{array}{l}\text { Have you experienced any } \\
\text { problems with the new catalogue } \\
\text { interface? }\end{array}$ & $\begin{array}{l}57 \text { answers. } 47 \text { had no problems: some were } \\
\text { quite enthusiastic about the new system, } \\
\text { while some said it was too early to tell. } \\
\text { Among the ten who did experience problems } \\
\text { with the new catalogue interface, some of the } \\
\text { issues weren't with VuFind but with our home } \\
\text { page. Two said they would like to be able to } \\
\text { mark and print, text, or email multiple } \\
\text { records, and that the system should } \\
\text { remember their cell phone number for } \\
\text { texting. }\end{array}$ \\
\hline 10 & $\begin{array}{l}\text { What do you like about the new } \\
\text { catalogue interface? (Free text } \\
\text { question) }\end{array}$ & $\begin{array}{l}66 \text { answers. Grouping them into general } \\
\text { categories showed the following as the most } \\
\text { popular: } \\
\text { - Easier to use (22) } \\
\text { - } \text { More attractive (17) } \\
\text { - } \text { Simple, clear, straightforward (12) } \\
\text { - }(7) \\
\text { - Rew features: texting, favourites (6) } \\
\text { - Easier to search and browse (5) }\end{array}$ \\
\hline 11 & $\begin{array}{l}\text { If you could change something } \\
\text { about the new catalogue interface } \\
\text { to improve it, what would it be? }\end{array}$ & $\begin{array}{l}58 \text { answers. There were two general } \\
\text { categories: }\end{array}$ \\
\hline
\end{tabular}




\begin{tabular}{|c|c|c|}
\hline & & $\begin{array}{l}\text { - Nothing (19) } \\
\text { Interface and search results too } \\
\text { cluttered (8) } \\
\text { Of the other answers there was a wide mix of } \\
\text { points, such as more information in emailed } \\
\text { results, the ability to select and print a set of } \\
\text { results, a mobile interface, and showing } \\
\text { when an item was on a course reading list. }\end{array}$ \\
\hline 12 & $\begin{array}{l}\text { Would you recommend the new } \\
\text { catalogue interface to a friend or } \\
\text { colleague at York? }\end{array}$ & $\begin{array}{l}\text { - Yes: } 68(91 \%) \\
\text { - } \quad \text { No: } 3(4 \%) \\
\text { - } \text { Other (uncertain): } 4(5 \%)\end{array}$ \\
\hline 13 & $\begin{array}{l}\text { Do you like the new catalogue } \\
\text { interface ... (checkboxes) }\end{array}$ & $\begin{array}{l}\text { - More than the current catalogue: } 61 \\
\text { ( } 83 \%) \\
\text { - Less than the current catalogue: } 3 \\
\text { ( } 4 \%) \\
\text { - I don't use the current catalogue: } 1 \\
\text { ( } 1 \%) \\
\text { Other: } 9(12 \%) \text { (five liked it about the } \\
\text { same) }\end{array}$ \\
\hline
\end{tabular}

\section{Discussion}

The survey and usability testing surfaced a number of issues both positive and negative which are discussed below including: a) rich search results, b) Web 2.0 features, c) deconcatenated Library of Congress Subject Headings, d) subject searching using Library of Congress Subject Headings, e) electronic resources, f) facets, g) date versus relevancy ordering of results, and h) finding a known journal title.

\section{a) Rich search results}

The VuFind results listing was very different from the old WebCat results (see Figures 5 and 6 ). It included almost all the basic information users needed: title, author, date, location, call number, and book cover (if available). Because of this, in the usability testing (question 2.1), everyone immediately found a copy of Othello on the search results page. However, availability status was not displayed on the results page, therefore to identify if an item was available the user needed to view the record display page. To address this issue, after usability testing we added availability to the results listings. It was clear that for most searches, users would stop on this page and not dig deeper to view the full item record. One possible implication of this is that there will be fewer item record views (hence fewer page views) and apparently less use of the discovery layer compared to the old catalogue, even though users' information needs are being more quickly satisfied. 


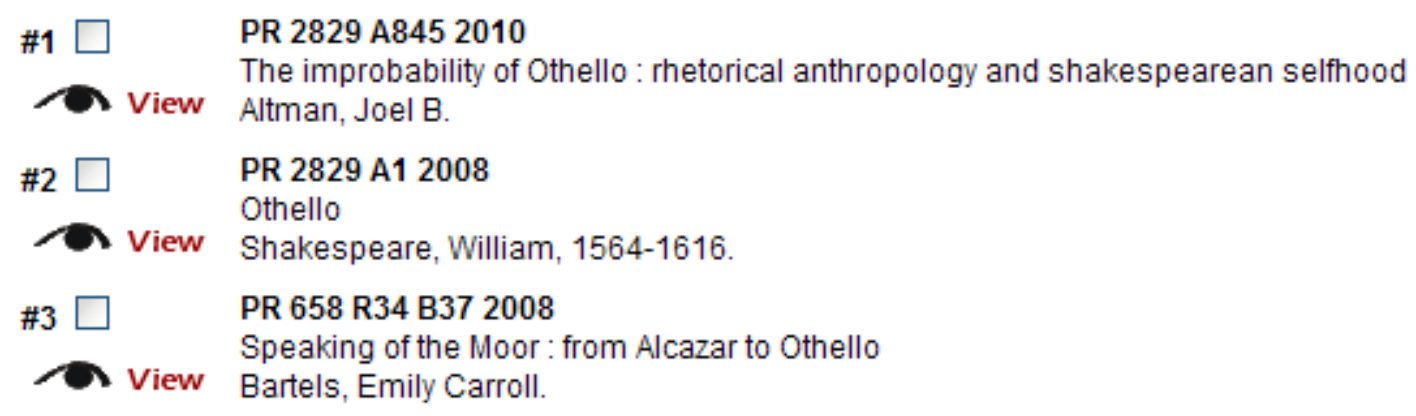

copies: 1 (SC

at: YORK

pubyear: 2010

copies: 1 (SC

at: YORK

pubyear: 2008

copies: 1 (SC

at: YORK

pubyear: 2008

Figure 5: Search results in WebCat

1. Othello

By:

Shakespeare, William, 1564-1616

Other Authors: Snodgrass, Mary Ellen | Shakespeare, William, 1564-1616

Published: 2008

Format: $\quad$ Book

Call Number: PR 2829 A1 2008

Availability: Scott Library 1 Available

2. Othello

By:

Shakespeare, William, 1564-1616

Other Authors: Muir, Kenneth

Published:

2005

Format:

目 Book

Call Number:

PR 2829 A2 M84 2005

Availability:

Scott Library 1 Available on Reserve

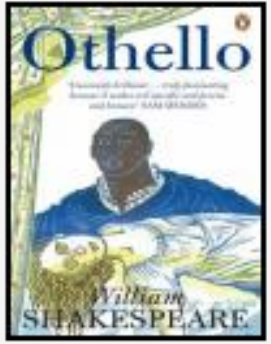

Figure 6: Search results in VuFind showing all the basic information students need to find materials (availability is in green)

\section{b) Web 2.0 features}

Unlike the classic catalogue, VuFind has a favourites system that lets users mark, tag, comment on items, and save them for later reference. We wanted to test this functionality and determine if users would see the "Add to Favourites" link near the top of the item record display and then if they could easily add an item to that list. Most participants were successful with adding an item to their Favourites list, however, some were confused with the language and thought that they were adding a bookmark in Internet Explorer. For this reason we later changed the language to "My List." When adding a favourite, a small modal window would appear, greying out the page behind it. It had two text fields (tags and comment) but showed no title, author or other information about the item. Participants were confused about how much information the system itself would store about the item they were marking. 
For this reason most of them entered the title and author's name. To address this issue, we added all of the basic bibliographic information to the modal window. After saving, there was no noticeable indication that anything had happened. The modal window went away and the original page came back, but the users did not notice the Favourites link was now shaded a very faint yellow (the "yellow fade technique"). We added this to our future developments list.

\section{c) Deconcatenated Library of Congress Subject Headings}

Usability testing of the deconcatenated subject headings (question 7.2, "How would you find more on the subject of modern literature of the twentieth century, specifically history and criticism?") had a 90\% success rate. One user said, "Yes, 'Literature, Modern' would be the most broad, '20th Century' would narrow it down more and 'History and criticism' would narrow it even more." Another tried two different links, noticed the results counts, and deduced the behaviour: "Yes, if I clicked on '20th Century' I get 718, if I click on 'History and criticism' I get 536." A third said, "What's kinda nice is that I can see how broadly I want something related to it or how narrow... It seems like eBay. Like a shopping site, with so many items."

This is an example of a new feature in a discovery layer that should have previously existed in OPACs. Our implementation and users' familiarity with breadcrumbs and hierarchy on other sites meant it was well understood.

\section{d) Subject searching using Library of Congress Subject Headings}

Usability question 8.1 was designed to test finding resources on a given subject and navigating VuFind's use of LCSH. It had a dismal success rate of $20 \%$. The two successful users did a keyword search on the words "cell biology." We would also have counted as a success a Subject Keyword search on "cytology" (the LCSH preferred term). We did not count as a success what the remaining eight did: a Subject Keyword search on "cell biology." Three users did the search with quotes, getting 10 results about "Tight junctions (Cell biology)," the only LCSH term containing the phrase "cell biology." Five users did the search without quotes, getting 116 results where the words "cell" and "biology" appeared anywhere in any subject headings. None of the users had a background in biology and they had no idea they were not seeing the library's full holdings on the topic of cell biology. Similarly, Antelman et al. (2006) found that a significant number of tasks failed using the Endeca catalogue because people selected Keyword in Subject rather than Keyword Anywhere searches (p. 135). It became clear that students were not aware that "Subject Keyword" was searching LCSH. They did not realize they were searching a controlled vocabulary, and LCSH is not exposed as it is in some databases where the thesaurus is searchable and browsable. To address this issue we changed the option from "Subject Keyword" to "Subject Heading" and added a hint that explained LCSH was used. Follow-up testing is needed to assess if users understand they are searching LCSH.

\section{e) Finding a known journal title}

We knew from previous usability testing, and research such as Cockrell and Jayne (2002), that finding an article given a citation is difficult. VuFind would not solve the problem, because we are not including article-level metadata. The most efficient way is to find the journal first, then search within it for the article or drill down to the volume and issue. To avoid confusion around this, instead of asking users to find an article we asked them to find a specific issue of a journal (Aging Cell, volume 8, number 3, from June 2009). Even so, this question only had a success rate of $20 \%$. 
There were two main problems. First was the lack of a periodical title search, which several people looked for because it existed in the classic catalogue. Second and more important was the lack of clear and understandable holdings information. When the users saw the listing for Aging Cell in the search results, it said "2002," the date the journal began publishing. Users thought that if they followed that link they would only see the issues of Aging Cell from 2002, so they tried to find 2009 somewhere else and failed. To solve this we changed the display to show the date our coverage began, appended "to current" where there was no close date, and listed the databases where the journal would be found.

The survey results indicated that twenty-one of 75 respondents were looking for articles, similar to results found at Yale (Bauer 2008b). One comment was that "there are no scholarly articles on the Junction in Toronto," and "I still haven't figured out where the articles button is." This will continue to be an issue until articles are loaded into our system.

\section{f) Electronic resources}

We wanted to discover if online resources should be included when results were narrowed to a particular branch. In usability question 8.6 we discovered that forty per cent said that limiting to a specific branch should include all of the eResources. One subject explained, "Yes, if I think of it like Toronto Public Library, [if] the electronic resources are not part of any one branch then they should all show for all of the branches." Fifty per cent thought that only items actually in that branch should be displayed. We decided to show eResources when the user limits to a specific branch. The user must then limit by format to see items actually physically in the branch. Although this was not what half of the students tested expected, we felt it was important that our eResources be discoverable and we wanted students to be able to make selection decisions by seeing the physical materials alongside the virtual materials.

\section{g) Facets}

Most users preferred VuFind to the old catalogue and particularly mentioned the facets. Several users commented on the item counts in the facet listing and that they did not add up to the total number of search results. One observed: "The numbers beside them do not seem to correlate with the total. For example Region still doesn't add up to 148." Another explained that this would affect his confidence in the reliability of the system, since it might not be accurate if the counts did not add up to the total number of hits. The Language field was also inaccurate, but for a different reason: not all items have a language defined in their MARC records. One student observed: "See ... the language, they don't write anything. When it's blank it's English?" This shows how a discovery layer can surface the inaccuracies, inconsistencies, and incompleteness of many records, and underlines the importance of quality cataloguing.

Although facets were a popular feature, "Era" and "Region" confused users. Several thought they were the date and place of publication, not the time period and area as subjects. These two facets were also sparsely populated and contributed to the confusion surrounding the total number of results. We removed them before the full launch of VuFind.

\section{h) Date vs relevancy ordering of results}

Whether to order search results by date or relevancy was a point of contention. 
The default VuFind configuration gave poor relevancy rankings, and it was the general feeling that we should use date ordering until relevancy was improved. Date had also been the default in the classic catalogue. This conclusion was supported by the usability testing: $40 \%$ of the subjects mentioned currency as being important when scanning a list of unfamiliar search results (see usability question 8.3), and this was also commented upon by a user in the survey results. However, when we launched VuFind in January 2010, we had many complaints about the date ordering as well as the lack of a left-anchored browse search. To address these two issues we improved the relevancy rankings by adjusting VuFind's field weightings in a configuration file, and switched to relevancy ordering in May 2010.

\section{Conclusion}

Our customized VuFind interface offered many improvements over our old WebCat catalogue. Instead of requiring users to search in two different places, VuFind provided a single search box that brought together not only the classic catalogue and our ERM but added material from our instances of DSpace and Open J ournal Systems. Both the usability testing and survey showed that VuFind's interface was intuitive and user-friendly. A very popular feature of VuFind was the rich search results showing all of the basic information needed to quickly and accurately find materials. Users found VuFind's "Add to Favourites" bookmarking feature to be easy to use. VuFind's deconcatenated Library of Congress Subject Headings were intuitively understood by users, who appreciated the extra power offered by this new functionality. However, our usability testing did show that when searching by subject it is important to communicate to users, through information literacy classes, etc., that they are searching LCSH and not natural language. With the discovery layer we were able to bring together physical and virtual holdings so that all available material was easily visible to users. Some users calculated the numbers of results in the different facets and were confused when they did not equal the total number of search results found. For this reason, and due to confusion surrounding terminology, we did not include Era or Region facets in our official launch of VuFind. Finally, finding articles has always posed a problem for library catalogue users, and while we identified and resolved some issues inherent in finding journals in VuFind, finding particular articles given a citation still presents a challenge to users.

These findings and improvements were, for the most part, implemented for the initial launch of our discovery layer in January 2010. We released two upgrades that year: in May relevancy rankings were improved, and in August an advanced search was added. Some of the other desired features we identified have since been implemented by the VuFind project developers, such as improved RSS feeds and Zotero integration. Other improvements we will need to develop ourselves include deduping the electronic resource listings and including personalized content with suggested links and resources based on a student's course of study. We will also be focused on creating a mobile interface. A basic mobile theme is currently available, but requires development before it can be made public. Finding what is essential to users in a mobile interface will require more usability testing, and when it is possible to load article-level metadata into the system, a completely new round of testing will also be needed. We hope that others will build on our testing questions and findings, as well as those by Antelman et al. (2006) and Bauer (2008b) to create a solid body of literature on usability testing of discovery layers. 


\section{References}

Antelman, K., Lynema, E. \& Pace, A.K. (2006), "Toward a twenty-first century library catalog", Information Technology and Libraries, vol. 25, no. 3, pp. 128.

Bauer, K. (2008a), "Usability test of VuFind as a subject-based display of ebooks", available at: https: //collaborate. library.yale.edu/usability/reports/Forms/public.aspx (accessed February 2011).

Bauer, K. (2008b), "Yale University Library VuFind test-undergraduates", available at: https://collaborate.library.yale. edu/usability/reports/Forms/public. aspx (accessed February 2011).

Bauer, K. (2008c), "Opinion survey of Yufind/Vufind", available at: https://collaborate.library.yale.edu/usability/reports/Forms/public. aspx (accessed February 2011).

Cockrell, B.J . \& Jayne, E.A. (2002), "How do I find an article? Insights from a web usability study", The Journal of Academic Librarianship, vol. 28, no. 3, pp. 122-132.

Fagan, J. (2010), "Usability studies of faceted browsing: a literature review", Information Technology and Libraries, vol. 29, no. 2, pp. 58.

Falvey Memorial Library, Villanova University "VuFind: The library OPAC meets Web 2.0", available at: http://vufind.org/ (accessed November 2010)

Ho, B., Kelley, K. \& Garrison, S. (2009), "Implementing VuFind as an alternative to Voyager's WebVoyage interface", Library Hi Tech, vol. 27, no. 1, pp. 82-92.

Large, A. \& Beheshti, J. (1997), "OPACs: a research review", Library and Information Science Research, vol. 19, no. 2, pp. 111-133.

Nielsen, J . \& Landauer, T.K. (1993), "A mathematical model of the finding of usability problems", Proceedings of the INTERACT '93 and CHI '93 Conference on Human Factors in Computing Systems, ACM, New York, pp. 206-213.

Nielsen, J. (2000), "Why you only need to test with 5 users", available at: http://www. useit.com/alertbox/20000319.html (accessed December 2010).

Nielsen, J. (2001), "Success rate: the simplest usability metric", available at: http://www. useit.com/alertbox/20010218.html (accessed December 2010).

Olson, T.A. (2007), "Utility of a faceted catalog for scholarly research", Library Hi Tech, vol. 25, no. 4, pp. 550-561.

Sadeh, T. (2008), "User experience in the library: a case study", New Library World, vol. 109, no. 1/2, pp. 7-24.

Yang, S.Q. and Wagner, K. (2010), "Evaluation and comparing discovery tools: How close are we towards next generation catalog?", Library Hi Tech, vol. 28, no. 4, pp.690-709. 
York University Libraries (2007), "LibQUAL+ 2007 Survey", available at: http: // www. library.yorku.ca/ccm/Home/LibQUAL/LibQUALSurvey (accessed November 2010). 